\title{
Midline raphe scroti artery flap for penile shaft reconstruction
}

\author{
Ursula Mirastschijski ${ }^{1,2}$, Carla Schwenke ${ }^{3}$, Igor Schwab ${ }^{4}$, Andreas Buchhorn $^{5}$, Andreas Schmiedl $^{5}$ \\ ${ }^{1}$ Mira-Beau gender esthetics, Berlin 10777, Germany. \\ ${ }^{2}$ Wound Repair Unit, CBIB, Faculty of Biology and Chemistry, University of Bremen, Bremen 28359, Germany. \\ ${ }^{3}$ Department of Urology, Josef-Hospital, Delmenhorst 27753, Germany. \\ ${ }^{4}$ Department of Plastic, Reconstructive and Aesthetic Surgery, Klinikum Bremen-Mitte, Bremen 28205, Germany. \\ ${ }^{5}$ Institute of Anatomy, Hannover Medical School, Hannover 30625, Germany.
}

Correspondence to: Prof. Dr. Ursula Mirastschijski, Wound Repair Unit, CBIB, Faculty of Biology and Chemistry, University of Bremen, Leobener Str./NW2, Bremen 28359, Germany. E-mail: mirastsc@uni-bremen.de

How to cite this article: Mirastschijski U, Schwenke C, Schwab I, Buchhorn A, Schmiedl A. Midline raphe scroti artery flap for penile shaft reconstruction. Plast Aesthet Res 2020;7:45. http://dx.doi.org/10.20517/2347-9264.2020.44

Received: 20 Mar 2020 First Decision: 20 Jul 2020 Revised: 26 Jul 2020 Accepted: 4 Aug 2020 Published: 21 Aug 2020

Academic Editor: Marlon E. Buncamper Copy Editor: Cai-Hong Wang Production Editor: Jing Yu

\begin{abstract}
Aim: To investigate a novel method for penile shaft reconstruction.

Methods: Penile tissue loss is caused by injury, infections, obesity or cancer resection. Reconstructive techniques comprise skin grafts with the risk of scarring and tissue rigidity. To develop an alternative reconstructive procedure, the pertinent vascular anatomy was studied on fresh cadavers instilled with red latex, which permitted the design of the midline raphe scrotal artery flap (MiRA). After anatomical proof-of-feasibility, penile reconstruction was performed in adult patients with classic buried penis or after cancer resection.
\end{abstract}

Results: Anatomical studies revealed a novel finding of two scrotal septa, each with the terminal branch of the internal pudendal artery. Pedicled on both arteries, a neurovascular island flap could be harvested. In the presence of excess scrotal tissue, the entire circumference of the penile shaft could be covered by this flap. Patients with penile skin defects and excess scrotal tissue were eligible for flap harvest. The flap was raised either as an extended island flap pedicled on both septal arteries for complete penile shaft coverage, or as a VY-flap for partial reconstruction; the donor site was closed primarily. Post-operative complications included swelling or partial wound dehiscence. There were no flap losses or perfusion problems. Patients reported full sensitivity to the penile shaft skin and sufficient skin elasticity for erection.

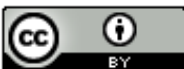

(C) The Author(s) 2020. Open Access This article is licensed under a Creative Commons Attribution 4.0 International License (https://creativecommons.org/licenses/by/4.0/), which permits unrestricted use, sharing, adaptation, distribution and reproduction in any medium or format, for any purpose, even commercially, as long as you give appropriate credit to the original author(s) and the source, provide a link to the Creative Commons license, and indicate if changes were made. 
Conclusion: The MiRA flap is a technically safe neurovascular flap suitable for the reconstruction of partial or full defects of the penile shaft, such as after type III buried penis surgery, and provides sufficiently elastic and sensitive skin for functional penile reconstruction.

Keywords: Scrotal anatomy, septal artery, penile shaft coverage, penile reconstruction, buried penis, scrotal island flap, midline raphe scrotal artery flap

\section{INTRODUCTION}

The penile skin is unique in that it has usually no hair and no subcutaneous fat layer. It is highly elastic and flexible, allowing for around a 2 -fold increase in penile length and a 1.5-fold increase in girth during erection $^{[1]}$. Hence, reconstruction of the penile envelope is difficult when most parts of the skin are lost.

Common causes for penile defects include infections such as Fournier's gangrene ${ }^{[2]}$, inflammatory reactions with tissue induration and granuloma formation after injection of various substances ${ }^{[3]}$, tumour resections ${ }^{[4]}$, trauma (e.g., burns ${ }^{[5]}$, combat ${ }^{[6]}$ or other related accidents ${ }^{[7]}$ ) or penile invagination into the pre-pubic fat apron in highly obese men ${ }^{[8]}$. With the rising incidence of morbid obesity, this phenomenon, also called buried penis, is increasingly seen in men with resulting impairment of micturition and sexual intercourse $e^{[\rho]}$.

Full- or split-thickness skin grafts are the current gold standard for the reconstruction of penile skin defects ${ }^{[10-12]}$. Draw-backs of this technically simple and straightforward procedure are the tendency for scarring and the rigidity of the skin graft once it has taken. Penile deviation or pain during erection with loss of penile length are commonly reported. Another reconstructive possibility is the use of scrotal skin. Despite the similarity of scrotal and penile skin - both are devoid of a subcutaneous fat layer and highly elastic - the reach of scrotal skin flaps is limited to the base of the penile shaft without the possibility of covering the entire shaft length ${ }^{[13]}$. Hence, temporary burying of the penis in the scrotum with delayed release, or local flaps for defects at the penile base are currently practised as well ${ }^{[14,15]}$.

The concept of plastic-reconstructive surgery is based on intimate anatomical knowledge of tissue structure and perfusion. The course of vessels enables the design of pedicled or free flaps to reach distant defects for closure. Despite its primitive function as a testicular bag, the scrotal sac has a pivotal role in maintenance of a man's reproductivity. The delicate regulation of temperature by the scrotum is orchestrated by an interplay of vessel width, muscle and skin contraction. As a consequence, vessels from different sources enter the scrotal sac to build a dense network. It is a well-known fact that branches from the external pudendal artery, also called rami scrotales laterales and anteriores, provide blood to the lateral and ventral scrotal skin, respectively. The internal pudendal artery sends branches to the dorsal part of the scrotum (rami scrotales posteriores), interacting closely with the branches of the external pudendal artery. Until recently, there was no information on arterial perfusion of the scrotal septum ${ }^{[16]}$.

In order to find novel surgical means to reconstruct the penile shaft, scrotal and penile anatomy and vessel distribution were anatomically studied on deceased body donors instilled with red ink into pelvic vessels first. After demonstration of the vascular anatomy of a scrotal island flap based on the arteries of both scrotal septa, patients with penile shaft defects were reconstructed with the novel neurovascular midline raphe scrotal artery flap (MiRA) island flap. 


\section{METHODS}

\section{Anatomical studies}

Initially, dissection studies were performed on cadavers at Hannover Medical School. Perfusion fixation was carried out via the femoral artery with a solution containing $2.7 \%$ paraformaldehyde $(n=4)$. Because the scrotal sac is positioned in the lower, dorsal parts of the supine laying body, a lot of liquid was found in the tissue which made vessel studies difficult. Furthermore, this fixation technique turned the normally soft and flexible genital tissue into a stiff matrix with rigid skin such that flap studies were impossible. Consequently, for flap surgery, fresh cadavers within $24 \mathrm{~h}$ of death were chosen. Male pelvic parts of fresh cadavers including the genitals $(n=4)$ were instilled with red silicone dye S 10 (KSK02A15.0 BIODUR ${ }^{\circ} \mathrm{S}$ 10; Biodur ${ }^{\circledR}$ Products GmbH, Heidelberg, Germany). Before vessel injection, the dye was mixed with the hardener S 6 (KSH03A1.o BIODUR ${ }^{\circ}$ Härter S 6) in a ratio of 100:5. The abdominal aorta was dissected and incised above the bifurcation. An anterograde tube was then inserted into the abdominal aorta above the bifurcation into both common iliac arteries. Using a $500 \mathrm{~mL}$ perfusion syringe, the colour suspension was pressed through the tube into the aorta by hand. The femoral artery was clamped below the exit of the profunda femoris artery. About $500 \mathrm{~mL}$ was injected. The solution was distributed over the internal iliac artery into the internal pudendal artery and over the external iliac artery into the external pudendal artery. After one-day of hardening, preparation of the vessels was started. Pictures were taken with a Nikon D5100 and a Nikon D800E camera.

For studies of the genital vasculature, the main vessels were prepared and branches to the scrotal sac and penis were followed. Of note, the testicular vasculature (funiculus spermaticus) was not dissected or investigated. First, the external pudendal artery was dissected at its origin in the groin or upper medial thigh and its course followed until the point of branching at the lateral aspect of the scrotal skin. Interestingly, there were variations with regard to its origin: directly from the femoral artery $(n=3)$, from the profound femoral artery $(n=2)$ and from the inferior epigastric artery $(n=1)$. Two donors had femoral artery surgery previously such that anatomical studies of the thigh vessels were impossible due to severe scarring and the presence of vascular implants.

For flap anatomy, incision markings were positioned as shown in Figure 1A-C, parallel to the midline scrotal raphe. After incision, the scrotal fasciae were dissected carefully starting from the most caudal point of the flap [Figure 1D-F]. The septum was visualized. Due to the prominent visibility of the septal vessels, with the terminal branch running from the dorsal aspect of the septum like an arch to the ventral plane of the scrotum, a second vessel was noticed with the same course but in a different plane. After further dissection, it became clear that the scrotal midline is separated beneath the raphe by two septa each containing one terminal branch of the internal pudendal artery on each side. Considering the embryology and the fact that the scrotal sac is formed by the fusion of two embryonal swellings, this observation is not the least surprising but rather, a logical consequence of embryological development. We could also demonstrate a dual septum with separate vessels which were communicating with each other. Next, the flap was pedicled on both septa and septal arteries, and lateral branches communicating with the central branches were dissected, retaining those branches that inserted directly into the flap. The septa at the dorsal aspect of the scrotum were released up to its cranial root and until sufficient mobility of the flap for penile shaft coverage was achieved. The flap was wrapped around the penile shaft and closed at its dorsal aspect [Figure 1G-I]. Because scrotal tissue is highly elastic, and due to pre-existing excessive cutaneous tissue, the donor site was closed primarily after orchidopexy [Figure $1 \mathrm{H}$ and I]. Because the flap and its vascular pedicle were designed around the scrotal midline, which is also called raphe, the flap was named the MiRA flap.

The novel finding of the scrotal anatomy with presence of two scrotal septa including an arch forming terminal branch of the internal pudendal artery is shown in detail in Figure 2. Since the scrotum is 

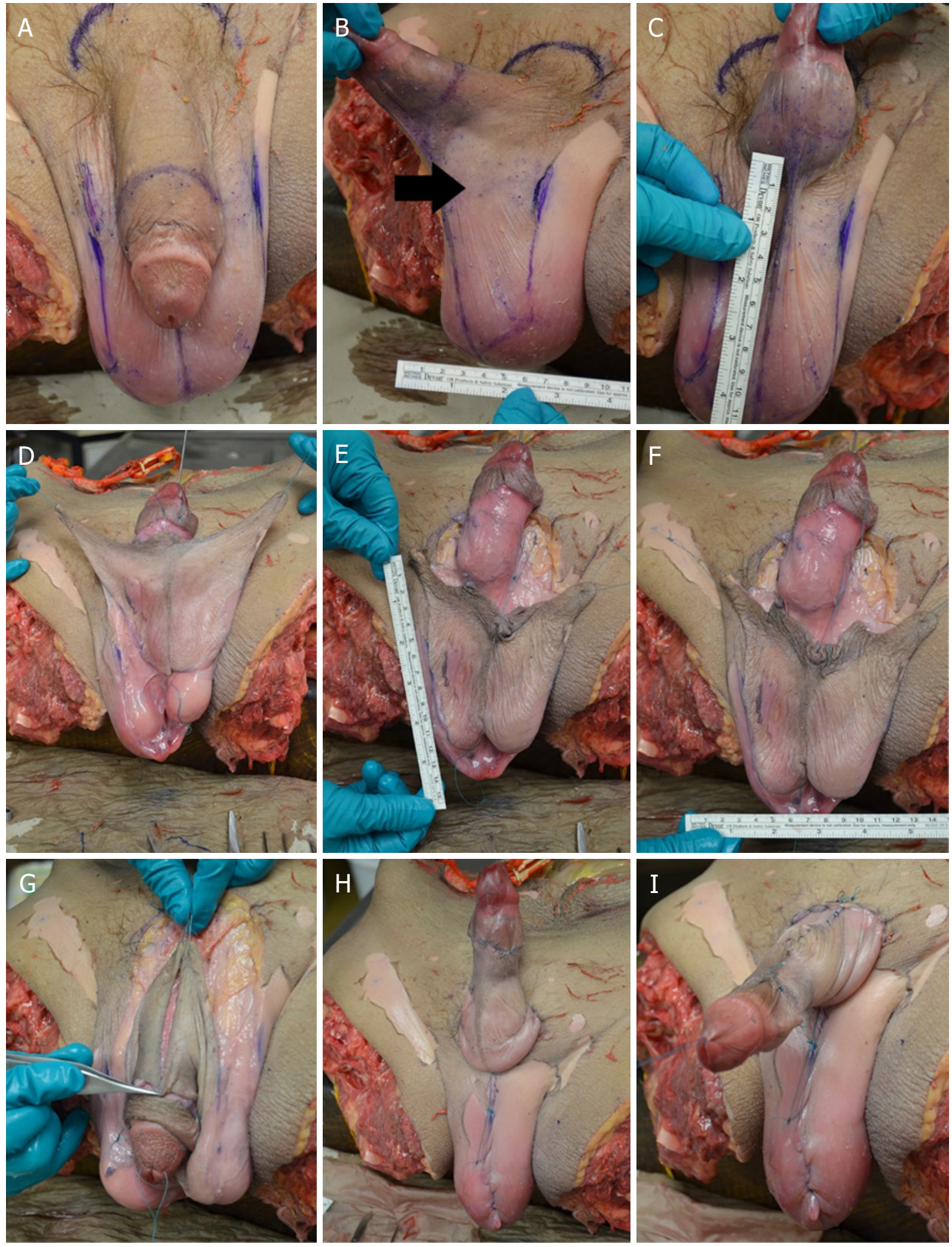

Figure 1. Representative images of anatomical studies on fresh cadaversare presented. A-C: pre-operative anatomical markings of the external genital region with a circumcised penis, excessive scrotal tissue and peno-scrotal webbing (B, arrow); D-F: flap mobilization and measurements of approximately $11 \mathrm{~cm}$ in length (E) and $7 \mathrm{~cm}$ in width (F); G-l: penile defect coverage (G) and donor site closure (H, I) are demonstrated 


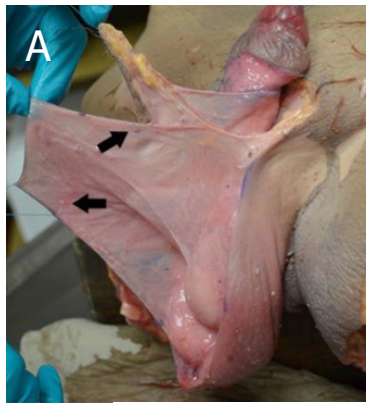

E

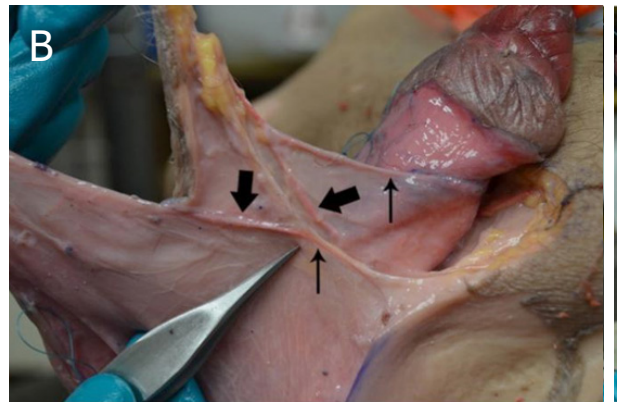

External pudendal

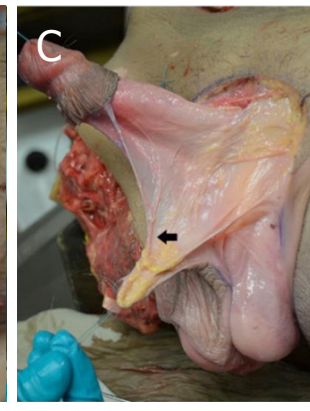

Penile shaft ventral aspect with corona glandis

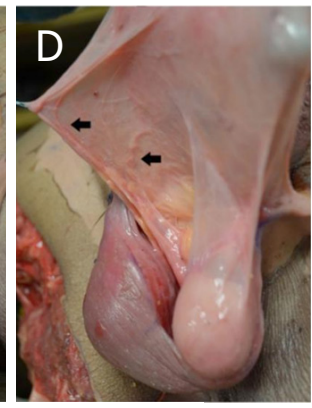

artery and vein vesscls

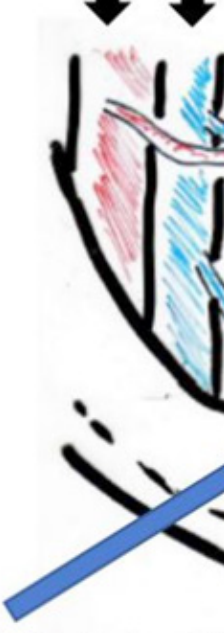

Medial extension of the Alcock channel containing internal pudendal vessels and nerve

\section{Funniculus} spermaticus

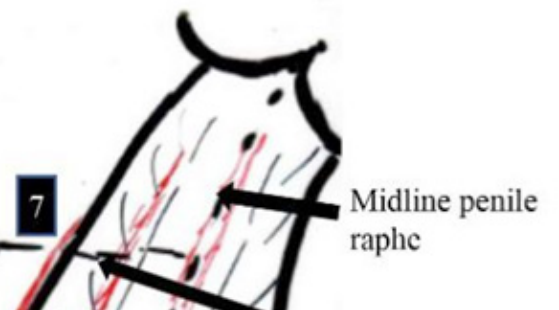

10
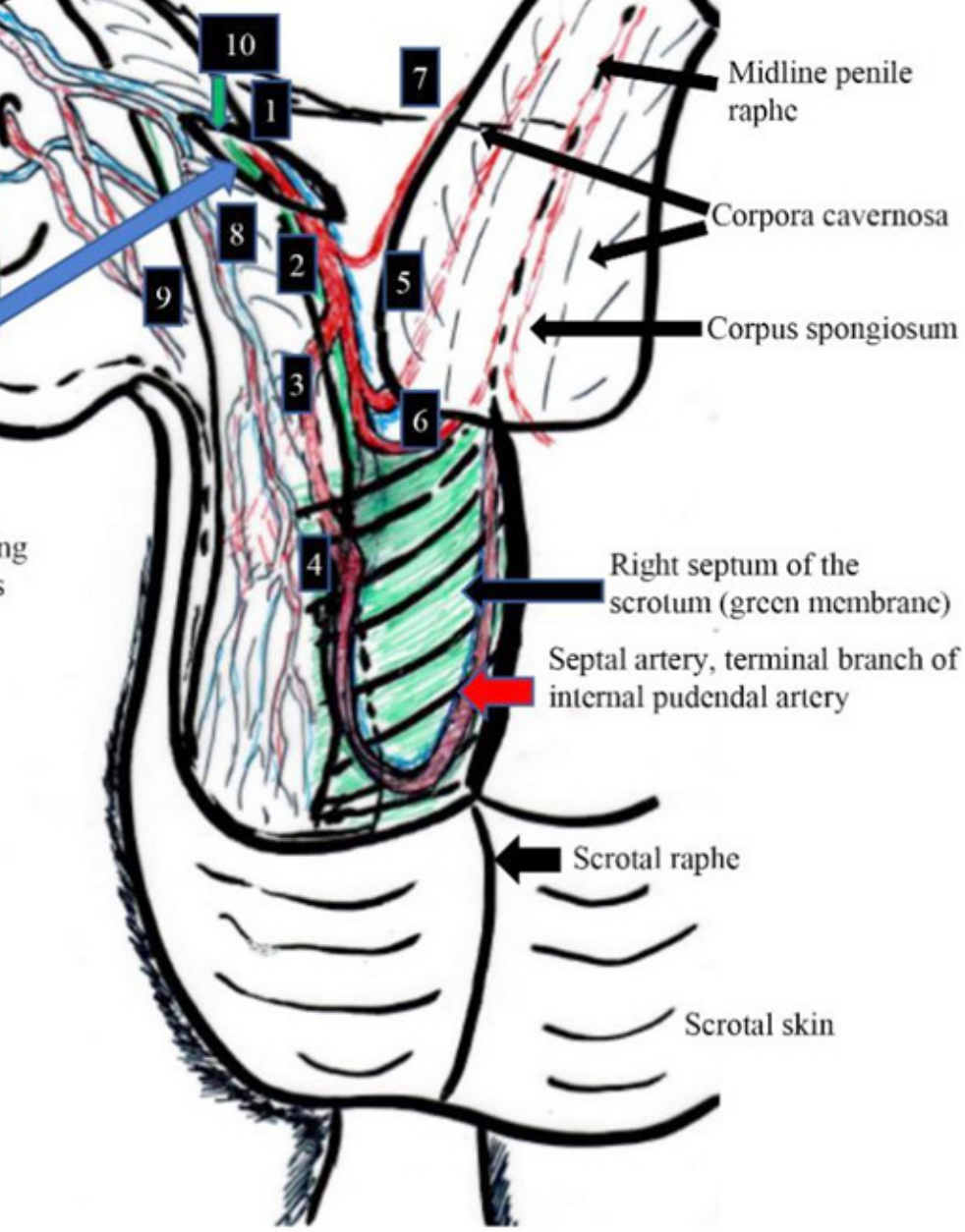

Figure 2. Septal anatomy with demonstration of the dual presence of scrotal septa including an arch forming terminal branch of the internal pudendal artery that is running from the dorsal to the ventral aspect of the septum. A: lateral view with the flap folded behind the septa. Arrows depicting the septal artery of each septum; B: close-up of A with the septal arteries (thick arrows) and anastomoses with lateral scrotal branches derived from the external pudendal artery (thin arrows); C: septal artery with anastomoses to the lateral border of the flap; D: close-up of the left septum with upper arrow depicting the septal artery. Lower arrow pointing to the artery of the right septum that is visible shining through the tissue layer of the left septum; E: graphical overview of the vascular anatomy of the scrotum. The scrotum is vascularized by the anterior, lateral and posterior branches of different arteries. The main vessels of the scrotum are the internal and external pudendal artery. After leaving the Alcock channel (ischiorectal fascia, blue long arrow), the internal pudendal vessels (1) divide into the rectal (not shown) and perineal artery (2). The dorsal scrotal branches (3) originate from the perineal artery which continues in the midline as the septal artery (4, red arrow). Further branches of each internal pudendal artery are the central arteries - providing the ipsilateral cavernosal bodies (5) and the corpus spongiosum (6) - and the dorsal penile artery (7). The anterior (8) and lateral (9) scrotal branches derive from the external pudendal artery originating from the femoral artery. Of note, the pudendal nerve (10, green arrow) accompanies the internal pudendal artery and its branches throughout the scrotum and penis 
Table 1. Demographic data of patients included in the study

\begin{tabular}{|c|c|c|c|c|c|c|}
\hline $\begin{array}{l}\text { Patient } \\
\text { number }\end{array}$ & Diagnosis & Co-morbidities & $\begin{array}{c}\begin{array}{c}\text { Previous genital } \\
\text { operations }\end{array} \\
\end{array}$ & Age (years)^ & BMI $\left(\mathrm{kg} / \mathrm{m}^{2}\right)$ & $\begin{array}{l}\text { Follow up } \\
\text { (months) }\end{array}$ \\
\hline 1 & Buried penis Grade III & $\begin{array}{l}\text { Diabetes type II, } \\
\text { hypertension } \\
\text { benign prostatic } \\
\text { hyperplasia }\end{array}$ & Circumcision & 74 & 35.1 & 6 \\
\hline 2 & Buried penis Grade III & $\begin{array}{l}\text { Diabetes type II, } \\
\text { hypertension, morbid } \\
\text { obesity }\end{array}$ & Circumcision & 63 & 40.5 & 12 \\
\hline 3 & Buried penis Grade III & $\begin{array}{l}\text { Diabetes type II, } \\
\text { hypertension }\end{array}$ & $\begin{array}{l}\text { Circumcision, recurrent } \\
\text { phimosis }\end{array}$ & 63 & 38.5 & 6 \\
\hline 4 & Buried penis Grade III & $\begin{array}{l}\text { hypertension, } \\
\text { hyperuricemia, morbid } \\
\text { obesity }\end{array}$ & $\begin{array}{l}\text { Circumcision due } \\
\text { to } L S C^{\star \star} \text {, recurrent } \\
\text { phimosis }\end{array}$ & 56 & 50.7 & 12 \\
\hline 5 & Penile cancer & $\begin{array}{l}\text { Compensated } \\
\text { cardiac insufficiency, } \\
\text { hypertension }\end{array}$ & $\begin{array}{l}\text { Cancer resection } \\
\text { (Buschke-Lowenstein- } \\
\text { Tumor) }\end{array}$ & 80 & n.d. & 0 \\
\hline
\end{tabular}

${ }^{\star}$ at the time of operation; ${ }^{\star \star}$ LSC: Lichen sclerosus et atrophicus; BMI: body mass index; n.d.: no data. Classification of the buried penis according to Mirastschijski ${ }^{[9]} 2018$

vascularized by the anterior, lateral and posterior branches of different arteries, a schematic overview of the vascular perfusion is shown in Figure 2E.

\section{Patient selection for reconstructive surgery}

Male patients $(n=5)$ with genital defects after tumour or with classic buried penis type III according to the previously published classification ${ }^{[9]}$ were selected for penile shaft reconstruction with the novel MiRA flap. After thorough discussion and informed consent was obtained, elective reconstructive penile surgery took place at the Department of Plastic, Reconstructive and Aesthetic Surgery or the Department of Urology at Klinikum Bremen-Mitte, Bremen, Germany, in the years 2016 and 2017. The prerequisite for choosing patients suited for this type of surgery was: (1) a penile shaft defect of the entire penile length; (2) sufficient scrotal tissue and; and (3) written consent for the operation and photo-documentation.

The mean follow-up was around 7 months. The post-operative follow-up of patients 1 to 3 was uneventful except for initial swelling and minor wound dehiscence. Patient 4 needed partial flap removal due to recurrent LSC which had formed beneath the neo-preputium of the flap. Patient 5 received out-patient care for penile cancer with his urologist and was lost from follow-up. For more detailed information see Table 1.

\section{Surgical technique MiRA flap}

Preoperatively, incision lines were marked on patients in the upright and supine position [Figure $3 \mathrm{~A}]$. The midline of the scrotal sac, the raphe scroti, is the central part of the flap because it depicts the insertion point of the scrotal septa and the position of the supplying vessels, i.e., the end branches of the internal pudendal artery. Incision lines are marked bilaterally from the midline/the raphe scroti with a V-or W-shape at its distal mobilization point. A scrotal examination was performed to confirm the presence of both testes in the scrotal sac and absence of inguinal hernias. Furthermore, the presence of excess scrotal tissue, also called peno-scrotal-webbing, was marked for flap harvest. Diagnosis of the stage of the adult buried penis was performed according to the adult buried penis classification ${ }^{[17]}$. Prior to surgery, the genital area was shaved. Patients were placed supine, washed with medical soap and disinfected. First, diseased tissue was excised, e.g., sclerotic Lichen sclerosus skin lesions or in one case, a penile carcinoma of the glans. All excised tissue was submitted for histopathological analysis. Patients presenting with adult buried penis were treated according to the previously published algorithm ${ }^{[17]}$. In short, after liposuction, the pre-pubic fat apron was excised. The buried penis was retrieved and the area for flap reconstruction measured with a ruler. The size of the MiRA flap was designed accordingly [Figure $3 \mathrm{~B}$ and $\mathrm{C}$ ]. After 

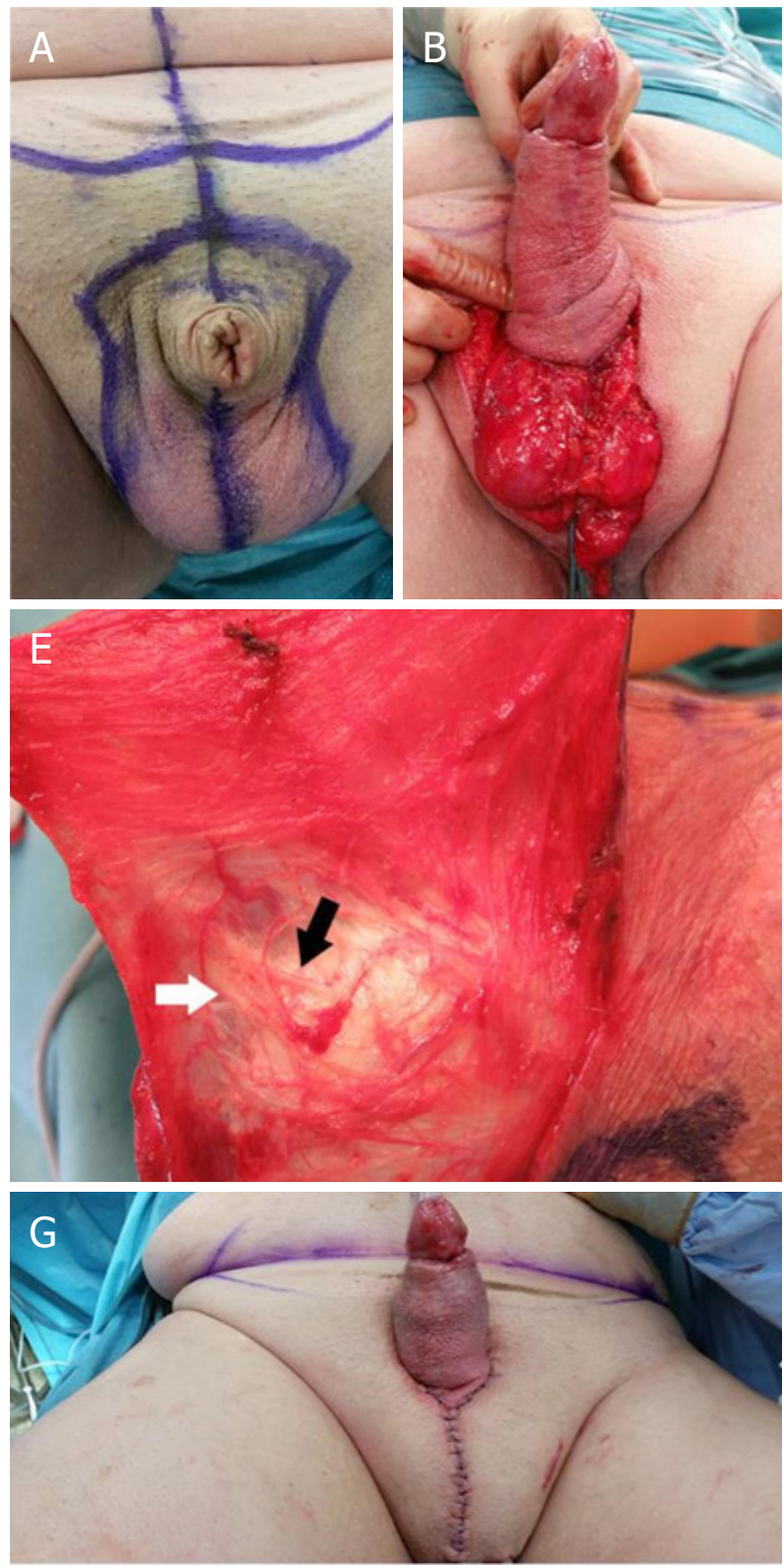
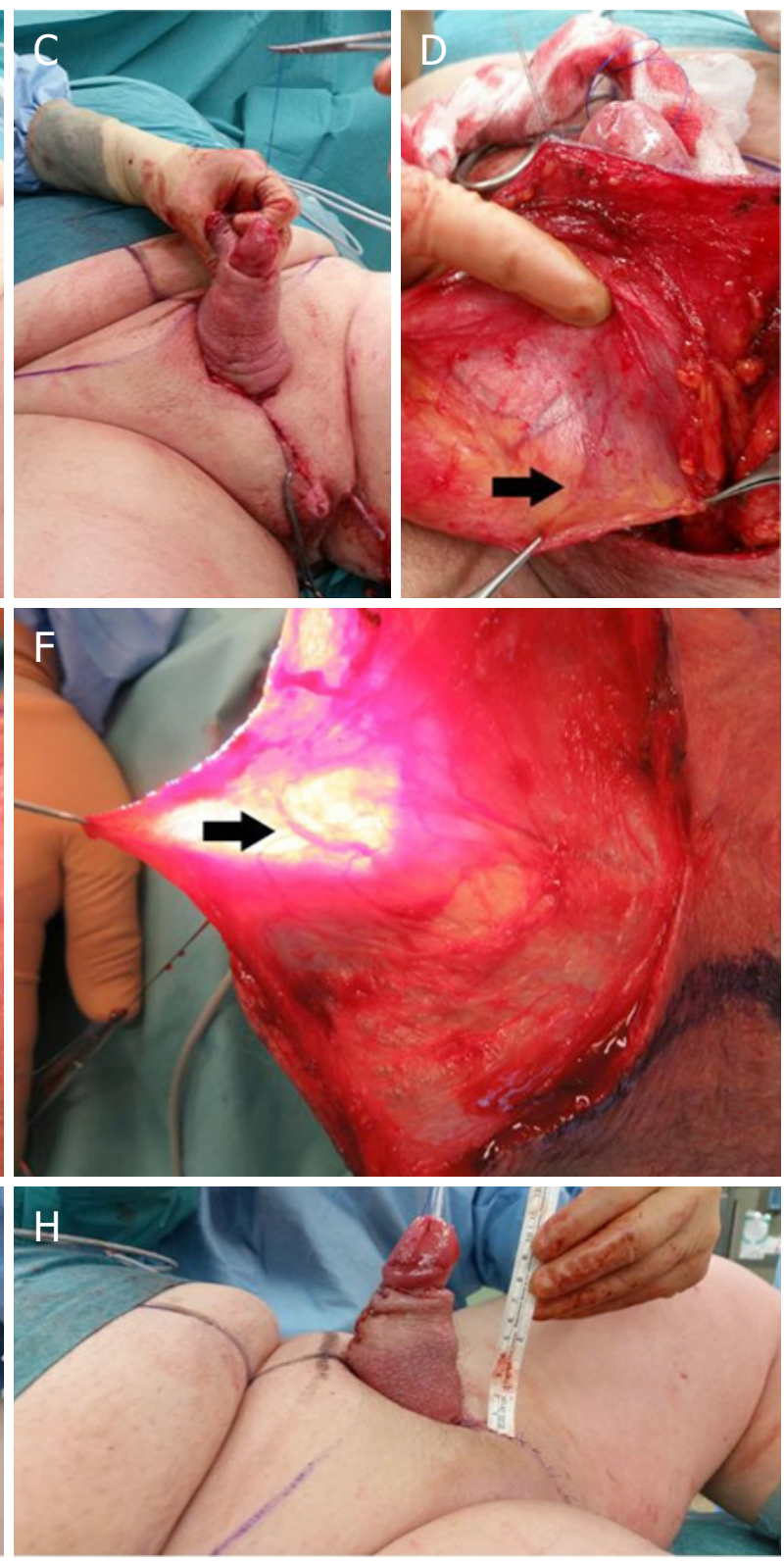

Figure 3. The surgical technique of the midline raphe scrotal artery flap is presented. A: preoperative markings; B: flap harvest and positioning around the penile shaft with complete coverage; C-F: the terminal branch of the pudendal artery runs in an arch-formed way from the dorsal plane of the septum to the ventral side. The black arrow depicts the artery (D-F), the white arrow depicts the concomitant nerve (E); G, H: postoperative result after wound closure. Visualization of the septal artery by diaphanoscopy in $\mathrm{F}$

incision, the flap was raised on both septal arteries preserving both septa underneath the island flap [Figure 3D-F]. Vascular branches anastomosing with lateral vessels were sealed using LigaClips ${ }^{\circ}$. The flap was mobilized, freeing both septa from its caudal fixation in the scrotum up to the cranial fixation point at the penile base so that it could be easily wrapped around the entire penile shaft. Closure of the scrotal sac was performed after bilateral orchidopexy, thorough hemostasis and drain placement. Due to excessive and elastic scrotal tissue, the donor site defect was closed primarily after mobilization of the wound edges with subcutaneous absorbable single knots and intradermal running sutures after inserting a Penrose drain [Figure $3 \mathrm{G}-\mathrm{H}$ ]. The prepubic wound was closed according to plastic-surgical standards with fascial anchoring sutures after Baroudi and Ferreira ${ }^{[18]}$ to avoid seroma formation and recurrence of penile retraction into the prepubic tissue. For penile shaft reconstruction, the MiRA scroti island flap, pedicled 
on both septal arteries, was wrapped around the penile shaft and closed with subcutaneous resorbable (e.g., 3.0 Vicryl) and cutaneous non-absorbable (e.g., 3.0 Ethilon) single knots sutures. Because of postoperative swelling, single knot sutures are preferred to avoid wound dehiscence. The reconstructed penis is then dressed using a fatty gauze to protect the skin of the flap. A stabilizing sponge is positioned around the penile shaft and secured with staplers at the penile base and with sutures (3.0 Prolene, blunt needle) to the glans. Aside from stabilizing the flap to the penile shaft, the sponge inhibits excessive post-operative swelling and lymphedema as well.

\section{RESULTS}

Five patients were included in the study after providing informed consent to the operation and to anonymous publication of their photographs. Demographic data of the patients is listed in Table 1. Mean post-operative follow-up was around 7 months. The surgical method was performed in each of the patients without any complications. In each patient, the scrotal septum consisted of two membranes as found in the anatomical study. In each septum, an arch-shaped terminal branch of the internal pudendal artery was identified exactly underneath the scrotal raphe, which served as a surgical landmark. Therefore, all island flaps were supplied by a dual arterial system. In all cases, excessive scrotal tissue was present to provide sufficient material for the island flap. In four cases of patients with adult buried penis, the complete penile shaft was grafted with the MiRA flap. Figure 4 depicts an example of a patient with buried penis grade III [Figure $4 \mathrm{~A}$ and B]. Initial swelling was reduced after 4 weeks post-operatively [Figure $4 \mathrm{C}$ and D]. After one year, the patient was very satisfied with the result including the neo-foreskin [Figure $4 \mathrm{E}$ and $\mathrm{F}$ ]. No recurrence of the buried penis was noticed in any of the monitored cases. In one case, a partial ventral shaft defect was covered with the flap after excision of a carcinoma of the glans that had grown into the ventral skin [Figure 5]. The surgical procedure was performed by two independent surgeons. Post-operative complications included a moderate hematoma $(n=1)$ without the need for intervention and lymphedematous swelling which is very common for the genitalia. In two cases, a wound dehiscence occurred followed by secondary suture after reduction of the swelling. Long-term results included lymphedematous swelling that resolved after six to eight weeks and the recurrence of pre-existing Lichen sclerosus et atrophicus in one patient with the need to excise part of the flap which had formed a neo-foreskin covering the glans completely. Patients were highly satisfied and reported immediate sensation to the penile shaft after the operation, and of enhanced erectile activity - which might have derived from the penile anchoring sutures.

\section{DISCUSSION}

Penile shaft reconstructive surgery had been hitherto limited to skin grafts with loss of tissue elasticity and sensitivity or to part-time burying the penis into scrotal tissue. Local flaps were restricted to the penile base with insufficient tissue to cover the complete length of the shaft. Here, we present a double artery pedicled midline scrotal island flap with complete cutaneous and sensitive restoration of the penile shaft.

The current gold standard for surgical penile shaft reconstruction are full- ${ }^{[17]}$ or split-thickness skin grafts ${ }^{[12]}$ with the disadvantages of post-operative shrinkage ${ }^{[10]}$, scarring and loss of elasticity and, as a consequence, reduced penile excursion which can impair erection and sexual intercourse. Major drawbacks of skin grafts are the complete loss of sensitivity to the penile shaft and partial reduction of the penile length in cases of graft shrinkage. The ultimate goal of our study was to find a surgical technique for full functional restoration of the penile shaft while at the same time remaining a simple surgical procedure suitable for patients with critical co-morbidities.

The use of scrotal tissue for penile shaft reconstruction is not novel. Scrotal skin is similar to penile skin in that it does not contain a subcutaneous fat layer and has a higher amount of elastic fibers than that found in non-genital $\operatorname{skin}^{[19]}$. In contrast to penile skin, it is thicker and contains hair and sebaceous 

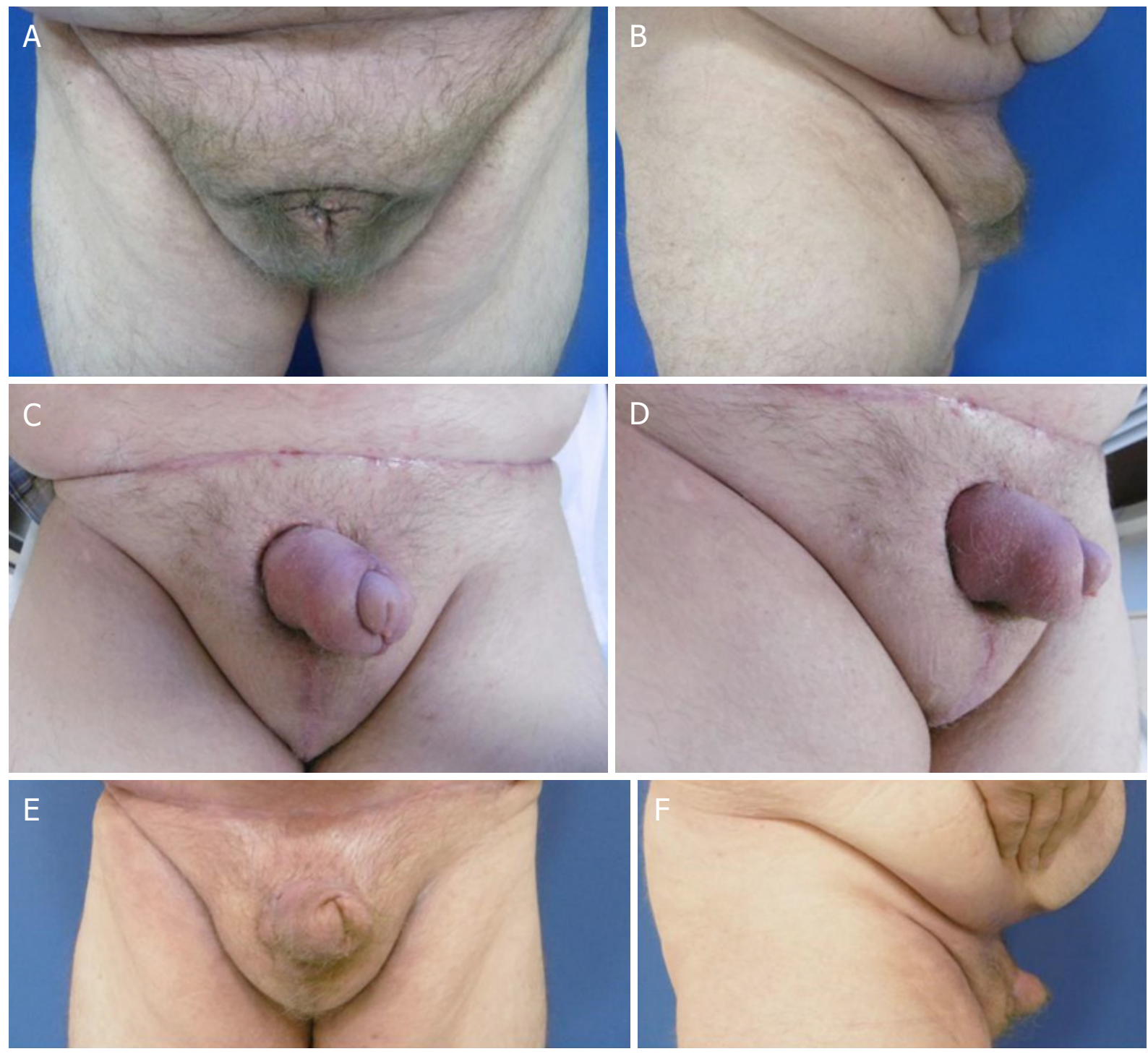

Figure 4. Pre- and postoperative example of a patient with buried penis type III and penile reconstruction with the MiRA island flap. A, B: preoperative view with completely invaginated penile shaft of a classic type III buried penis patient; C, D: postoperative result after 4 weeks; E, F: stable result after one year without recurrence of the buried penis and with neo-foreskin

glands. Several techniques were described to use scrotal skin for penile reconstruction, e.g., a scrotal dartos flap ${ }^{[20]}$, advancement flaps ${ }^{[13,21]}$ or a ventral slit scrotal flap ${ }^{[22]}$. The drawback of local advancement flaps is the limited reach with coverage of the penile base and parts of the penile shaft but not the entire length of the penis. The current urological golden standard for complete penile coverage is temporal burying of the penile shaft in the scrotal $\mathrm{sac}^{[14,23]}$. After 3 weeks, the flap is revascularized through penile vessels which permit retrieval of the penis with full shaft coverage by scrotal skin. Because the scrotal skin is completely released, no nervous continuity is provided and, as a consequence, there is no sensitivity to the shaft.

Anatomical studies on fresh cadavers were the prerequisite for the design of the novel flap presented in this study. The male genital anatomy is poorly delineated specifically with regard to scrotal vessels. Here, we describe for the first time the existence of two scrotal septa, each equipped with the terminal branch of the internal pudendal artery that runs from the dorsal wall of the scrotum within the septum to the ventral wall and anastomoses with lateral branches deriving from the external pudendal artery. Carrera et al. ${ }^{[16]}$ described in 2009 the central perfusion of the scrotal sac by two terminal branches of the internal pudendal 

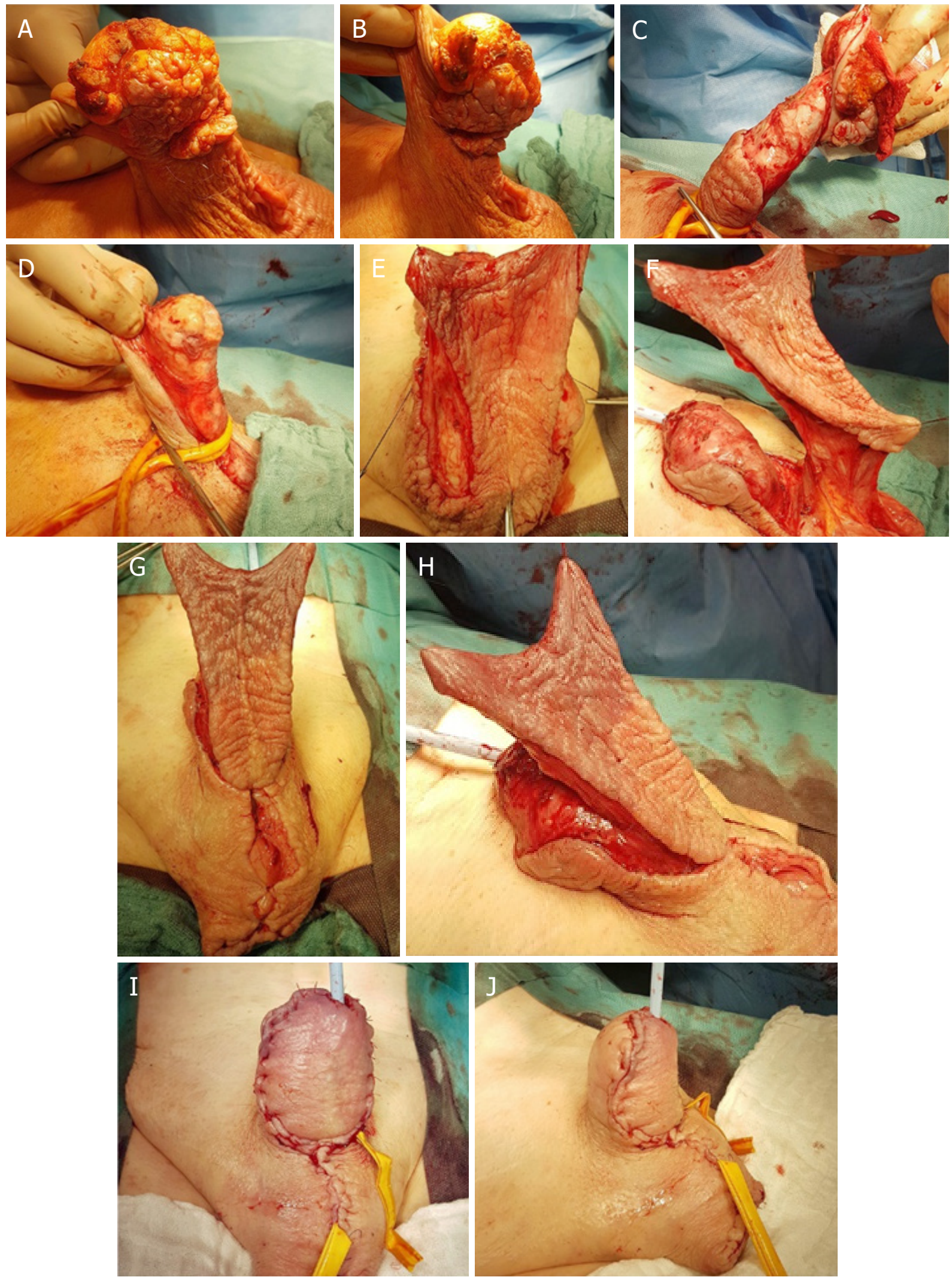

Figure 5. The MiRA flap is suitable for partial penile reconstruction in a patient presenting with a Buschke-Lowenstein tumor that extended onto the ventral side of the penile shaft. A, B: preoperative setting; $\mathrm{C}, \mathrm{D}$ : tumor resection including total glansectomy; $\mathrm{E}-\mathrm{H}$ : intraoperative view with flap harvest $(E, F)$ and closure of the donor site $(G, H) ; l, J$ : postoperative result with partial preservation of the penile shaft enabling micturition in the upright position 
artery, however, they did not discern that these arteries were running in parallel in two separate septa. A study by Angspatt et al. ${ }^{[24]}$ showed that the anterior scrotal artery supplies 62.5\%-100\% (mean 75.9\%) of the scrotal skin in the anteroposterior dimension and 66\%-100\% (mean 88\%) in the superoinferior dimension. The main blood supply runs through the branches of the external pudendal artery. The remaining tissue was supplied by the posterior scrotal artery. Seemingly, the dominant vascular system perfusing the scrotal tissue derives from the external pudendal artery with the anterior and lateral scrotal branches. The internal pudendal artery provides branches to the dorsal part of the scrotum and the septum.

During embryonal development, the external genitalia in both sexes originate from the genital tubercles and swellings. Under the influence of male or female hormones, genital swellings differentiate into the scrotum (dihydrotestosterone) or labia majora (estrogen) ${ }^{[25]}$. In females, the process continues with separation of the genital swellings that surround the vaginal vestibulum; in the male embryo, both genital swellings fuse in the midline to become the scrotal sac ${ }^{[25]}$. The scrotal septum depicts the fusion line of both genital swellings, and it is not surprising that it consists of two thin membranes with identical anatomical structure. Genital development is indeed common knowledge, however, the existence of two scrotal septa including a mirroring vasculature has not been described so far.

An island flap with dual arterial blood supply implies a safe surgical technique for penile shaft coverage. Both occlusion or disruption of the blood supply via one vessel will not jeopardize flap survival due to redundant blood supply by the twin artery. Our assumption is based on angiosome studies by Angspatt et al. ${ }^{[24]}$ and previous reports on the anatomy of the posterior scrotal artery ${ }^{[26]}$. The septal scrotal artery is a branch of the posterior scrotal artery deriving from the perineal artery [Figure $2 \mathrm{E}$ ]. In our anatomical studies, we could not clearly detect such angiosomes. Because the posterior scrotal artery anastomoses with branches of the lateral scrotal artery, it is conceivable that the angiosome may include the skin area around the raphe scroti along the septum scroti.

Interestingly, there are two further reports on scrotal island flaps with pedicles different from ours. Karim et al. ${ }^{[27]}$ used a dorsal scrotal island flap supplied by the dorsal scrotal vessels for perianal defect coverage. Fakin et al ${ }^{[28]}$ reconstructed patients with penile granuloma with a ventral scrotal flap pedicled on the deep external pudendal artery. Abundant bilateral cutaneous perfusion from different vascular sources with highly elastic and excessive tissue renders the scrotum an ideal donor area for reconstructive surgery. To avoid testicular torsion or ascension due to diminished volume of the scrotal sac after skin and septal resection, bilateral orchidopexy is recommended and should be routinely performed.

Nerves concomitant to the septal arteries provide cutaneous sensation over the ventral aspect of the scrotum in proximity to the midline where the flap is harvested. This unexpected finding was reported by our patients who were puzzled to locate the sensation of the neo-penile skin to the scrotal sac [Table 2]. In fact, the brain's plasticity enables even elderly patients to learn the new location of the skin within a few weeks, a well-known feature from reconstructive hand surgery ${ }^{[29]}$. In larger patient cohorts, objective measurement tools such as the Semmes Weinstein test for sensitivity analysis are recommended to evaluate clinical findings in a standardized way.

A general drawback of island flaps is the cessation of lymphatic drainage due to complete cutaneous excision with loss of lymphatic continuity [Table 2]. Consequently, a prolonged lymphedema is noticed until new lymphatic vessels have developed. To minimize swelling and the risk of wound dehiscence, a protective and stabilizing dressing is positioned circumferentially around the penis with fixation to the perineum and glans. After removal, manual lymphatic drainage and compression therapy are recommended. The highly elastic scrotal skin provides sufficient tissue to cover the entire penile shaft and can form a neo-prepuce as well. In case of patients with Lichen sclerosus et atrophicus (balanitis xerotica 
Table 2. Summary of outcomes with midline raphe scroti artery island flap

\begin{tabular}{ll}
\hline Pros & \multicolumn{1}{c}{ Cons } \\
\hline $\begin{array}{l}\text { Simple surgical technique, } \\
\text { sufficient perfusion due to the presence of two arteries, } \\
\text { intact sensibility due to the presence of cutaneous nerves }\end{array}$ & $\begin{array}{l}\text { Penile lymphedema, } \\
\text { wound dehiscence }\end{array}$ \\
Highly elastic tissue well-suited for size changes during erection & \\
Restoration of micturition & Postoperative compression therapy \\
Rehabilitation of sexual function & Bulkiness, \\
Prevention of recurrent buried penis & presence of hair \\
Reduction of excessive scrotal tissue & Scrotal size reduction, \\
Neo-foreskin & orchidopexy \\
& Contra-indication: LSC** \\
& Recurrence due to neo-foreskin \\
\hline
\end{tabular}

${ }^{\star \star}$ LSC: Lichen sclerosus et atrophicus

obliterans), a recurrence of the disease was noticed due to restoration of the moist and predisposing milieu for this skin disease. In this particular case, a revision with partial excision of the novel flap was indicated and the defect was covered with a skin graft.

In conclusion, the novel neurovascular MiRA island flap is well suited to reconstruct the entire penile shaft after tissue loss with restoration of a fully sensitive cutaneous envelope. Due to its abundant vascular perfusion via two septal arteries, it is a safe and easily performed surgical technique for a wide range of tissue defects of the male genitalia.

\section{DECLARATIONS}

\section{Authors' contributions}

Invention of the flap, surgical design in anatomical studies: Mirastschijski U

Surgical procedures in patients: Mirastschijski U, Schwenke C

Made substantial contributions to the conception and design of the study, performed data analysis, interpretation and acquisition, provided administrative, technical and material support, writing the manuscript, corrections and advice: Mirastschijski U, Schwenke C, Schwab I, Buchhorn A, Schmiedl A

\section{Availability of data and materials}

Not applicable.

\section{Financial support and sponsorship}

None.

\section{Conflicts of interest}

All authors declared that there are no conflicts of interest.

\section{Ethical approval and consent to participate}

An informed consent to participate in the study was obtained from each patient. For variation of standard surgical procedures, no ethical approval is needed.

\section{Consent for publication}

A written informed consent for anonymous publication of photographs was obtained from each patient.

\section{Copyright}

(c) The Author(s) 2020. 


\section{REFERENCES}

1. Schill S, Panfilov D, Mirastschijski U. Intimchirurgie beim Mann. In: Mirastschijski U, Remmel E, editors. Intimchirurgie. Berlin: Springer; 2019. pp. 49-67.

2. Sorensen MD, Krieger JN. Fournier's gangrene: epidemiology and outcomes in the general US population. Urol Int 2016;97:249-59.

3. Dellis AE, Arkoumanis T, Kyprianou C, Papatsoris AG. Paraffinoma, siliconoma and Co: disastrous consequences of failed penile augmentation - a single-centre successful surgical management of a challenging entity. Andrologia 2018;50:e13109.

4. Schwenke C, Melchior S. Peniscarcinom aus uro-onkologischer Sicht. In: Mirastschijski U, Remmel E, editors. Intimchirurgie. Berlin: Springer; 2019. pp. 207-13.

5. Harpole BG, Wibbenmeyer LA, Erickson BA. Genital burns in the national burn repository: incidence, etiology, and impact on morbidity and mortality. Urology 2014;83:298-302.

6. Balzano FL, Hudak SJ. Military genitourinary injuries: past, present, and future. Transl Androl Urol 2018;7:646-52.

7. McAninch JW, Kahn RI, Jeffrey RB, Laing FC, Krieger MJ. Major traumatic and septic genital injuries. J Trauma 1984;24:291-8.

8. Mirastschijski U. Buried penis. In: Mirastschijski U, Remmel E, editors. Intimchirurgie. Berlin: Springer; 2019. pp. 107-14.

9. Mirastschijski U. Classification and treatment of the adult buried penis. Ann Plast Surg 2018;80:653-9.

10. Garaffa G, Gentile V, Antonini G, Tsafrakidis P, Raheem AA, et al. Penile reconstruction in the male. Arab J Urol 2013;11:267-71.

11. Mirastschijski U, Schwenke C, Schmiedl A. Plastisch-chirurgische rekonstruktion des männlichen genitales. In: Mirastschijski U, Remmel E, editors. Intimchirurgie. Berlin: Springer; 2019. pp. 189-205.

12. Hakansson U, Kirrander P, Uvelius B, Baseckas G, Torbrand C. Organ-sparing reconstructive surgery in penile cancer: initial experiences at two Swedish referral centres. Scand J Urol 2015;49:149-54.

13. Qin X, Zhang S, Zhang H, Shen Y, Zhu Y, et al. Reconstruction with scrotal skin flaps after wide local resection of penoscrotal extramammary Paget's disease. BJU Int 2012;110:E1121-4.

14. Ziylan O, Acar O, Ozden BC, Tefik T, Donmez MI, et al. A practical approach for the correction of iatrogenic penile skin loss in children: scrotal embedding technique. Turk J Urol 2015;41:235-8.

15. Zhao YQ, Zhang J, Yu MS, Long DC. Functional restoration of penis with partial defect by scrotal skin flap. J Urol 2009;182:2358-61.

16. Carrera A, Gil-Vernet A, Forcada P, Morro R, Llusa M, et al. Arteries of the scrotum: a microvascular study and its application to urethral reconstruction with scrotal flaps. BJU Int 2009;103:820-4.

17. Mirastschijski U. Response to the letter to the editor. Ann Plast Surg 2018;81:508.

18. Baroudi R, Ferreira CA. Seroma: how to avoid it and how to treat it. Aesthet Surg J 1998;18:439-41.

19. Mirastschijski U. Genital scars. In: Téot L, Thomas M, Midlekoop E, Gauglitz G, editors. Textbook on scar management. Berlin: Springer; 2020.

20. Innocenti A, Tanini S, Mori F, Melita D, Innocenti M. Scrotal dartos-fascio-myo-cutaneous flaps for penis elongation after catastrophic iatrogenic skin shaft sub-amputation: a case of recovery using an extremely adaptable flap. Int J Surg Case Rep 2016;28:300-2.

21. Vaca EE, Mundinger GS, Zelken JA, Erdag G, Manahan MA. Surgical excision of multiple penile syringomas with scrotal flap reconstruction. Eplasty 2014;14:e21.

22. Westerman ME, Tausch TJ, Zhao LC, Siegel JA, Starke N, et al. Ventral slit scrotal flap: a new outpatient surgical option for reconstruction of adult buried penis syndrome. Urology 2015;85:1501-4.

23. Zucchi A, Perovic S, Lazzeri M, Mearini L, Costantini E, et al. Iatrogenic trapped penis in adults: new, simple 2-stage repair. J Urol 2010;183:1060-3.

24. Angspatt A, Pungrasmi P, Jindarak S, Tunsatit T. Bilateral scrotal flap: pedicle and dimension of flap in cadaveric dissections. J Med Assoc Thai 2009;92:1313-7.

25. Makiyan Z. Systematization of ambiguous genitalia. Organogenesis 2016;12:169-82.

26. Kulkarni AA, Bhatia SH, Abhyankar SV, Kulkarni MD, Singh RR. Posterior scrotal artery flap to cover a groin defect: a new technique. Indian J Surg 2013;75:52-3.

27. Karim RB, Hage JJ, Ahmed AK, Westerga J. Pedicled scrotal island skin flap in the treatment of anal basal cell carcinoma. Br J Plast Surg 2001;54:173-6.

28. Fakin R, Zimmermann S, Jindarak S, Lindenblatt N, Giovanoli P, et al. Reconstruction of penile shaft defects following silicone injection by bipedicled anterior scrotal flap. J Urol 2017;197:1166-70.

29. Rosen B, Lundborg G. Sensory re-education after nerve repair: aspects of timing. Handchir Mikrochir Plast Chir 2004;36:8-12. 